Springer Link

Data Management, Analytics and Innovation

Data Management, Analytics and Innovation pp 673-683| Cite as

\title{
A Transition Model from Web of Things to Speech of Intelligent Things in a Smart Education System
}

- Authors

- Authors and affiliations

- Ambrose A. Azeta

- Victor I. Azeta

- Sanjay Misra

- M. Ananya

Conference paper

First Online: 25 October 2019

Part of the Advances in Intelligent Systems and Computing book series (AISC, volume 1042)

\section{Abstract}

Several terms have been used to describe Internet of Things; Web of Things (WoT) is a term which can be used interchangeability and it is referred to as the capability of devices to interconnect to the World Wide Web and sharing the information and data to one another. WoT has been mentioned in the literature to improve interconnection between devices at all times. In WoT, two different modes of communication which are generally mentioned in previous studies include person-to-thing (or thing-to-person) and thing-to-thing. This paper presents an architecture for transiting from WoT to speech-enabled WoT known as Speech of Intelligent Things (SoIT). The system employs a combination of technologies such as system design, server-side scripting, speech-based system tools, and data management in developing the SoIT prototype system as a third mode of communication. This paper illustrates a scenario whereby remote monitoring and controlling of WoT devices within the university campus might be difficult to manage by only using the modes discussed in the literature. An evolution of WoT to SoIT was realized using speech technology to provide a prototype system. Technical implications involve using a telephone by connecting an object telephone number (OTN) and dial WoT objects and establish a control mechanism. The research limitation is mainly the cost of dialing an OTN number. The contribution of this paper is to favor and encourage the use of speech technology to enhance the convenience of communication between WoT devices within the school campus. 


\section{Keywords}

e-Campus OTN Speech interface SoIT WoT

This is a preview of subscription content, log in to check access.

\section{Notes}

\section{Acknowledgements}

We acknowledge the support and sponsorship provided by Covenant University through the Centre for Research, Innovation, and Discovery (CUCRID).

\section{References}

1. 1.

David, N.D.: How the internet of things is revolutionizing healthcare. In: White Paper. Healthcare Segment Manager, Freescale Semiconductor (2013)Google Scholar

2. 2 .

Adamkó, A., Kádek, T., Kollár, L., Kósa, M., Pánovics, J .: New challenges in smart campus applications. In: Recent Advances in Computer Science (2015)Google Scholar

3. 3.

Royer, M.: The Internet of Things (IoT). A trends white paper-August 2013. Bellevue College Economic \& Workforce DevelopmentGoogle Scholar

4. 4 .

Donald, S.: Parking on a Smart Campus: Lessons for Universities and Cities. Published by University of California Transportation Center (2005)Google Scholar

5. 5 .

Rohs, M., Bohn, J .: Entry points into a smart campus environment-overview of the ETHOC system. This work was conducted as part the Entry Points project, which is funded by the ETH World Program (2003)Google Scholar

6. 6 .

J ara, A.J ., Ladid, L., Skarmeta, A.: The internet of everything through IPv6: an analysis of challenges, solutions and opportunities. J oWua 4(3), 97- 118 (2013)Google Scholar

7. 7. 
Stefanie, T., Christoph, S.: A business model type for the internet of things. In:

Research in Progress. 22nd European Conference on Information Systems, Tel Aviv (2014)Google Scholar

8. 8.

Katole, B., Sivapala, M., Suresh, V.: Principle elements and framework of internet of things. Int. J . Eng. Sci. 3(5), 24- 29 (2013)Google Scholar

9. 9.

Gubbia, J ., Buyy, R., Marusic, S., Palaniswami, M.: Internet of things (IoT): a vision, architectural elements, and future directions. Future Gener. Comput. Syst. 29, 16451660 (2013) CrossRefGoogle Scholar

10.10.

Rambus: The Internet of Things. How Rambus Sees the Future. 2014 Rambus IncGoogle Scholar

Mattern, F., Floerkemeier, C.: From the internet of computers to the internet of things. In: Distributed Systems Group, Institute for Pervasive Computing, ETH Zurich (2010) Google Scholar

Abuelyaman, E.S.: Making a smart campus in Saudi Arabia. EDUCASE Q. 31(2), $10-12$ (2018)Google Scholar

Roman, R., Najera, P., Lopez, J .: Securing the internet of things. Computer 44(9), 5158 (2011) CrossRefGoogle Scholar

StaReport: The Internet of Things: Privacy and Security in a Connected World. Staff Report J anuary 2015. A Workshop Hosted by FTCGoogle Scholar

IEC: Internet of Things: Wireless Sensor Networks. White Paper (2014)Google Scholar

16. 16.

Ruggieri, M., Nikookar, H.: Internet of Things: From Research and Innovation to Market Deployment. Rivers Publisher's Series in Communication (2014) Google Scholar 
17.17.

Ravikanti, S., Preeti, G.: Future's smart objects in IOT, based on BigData and cloud computing technologies. Int. J . Innov. Res. Comput. Commun. Eng. 3(7), 6808-6817 (2015)CrossRefGoogle Scholar

18. 18.

Azure, M.S.: Get Started with the Internet of Things in Your Organization. Introducing Microsoft Azure Internet of Things services. Executive Summary. (c) 2015 Microsoft CorporationGoogle Scholar

19.19.

IBM: Saving the future of the IoT. IBM Institute of Business Value. Device Democracy (2005)Google Scholar

20.20 .

Barcena, M.B., Queest, C.: Insecurity in the IoT. Candid Wueest, Version 1.0 (2015) Google Scholar

Azeta, A.A.: Developing A computerized VoiceXML-based application for E-education: design, implementation and evaluation. Lambert Academic Publishing, Germany (2013)Google Scholar

22. 22.

Nati, M., Gluhak, A, Abangar, H., Headley, W.: Smartcampus: a user-centric testbed for internet of things experimentation. In: IEEE WPMC (2013)Google Scholar

23.23.

Voxeo: Voice voice server, available online at: http:// community.voxeo.com (2003)

24. 24 .

Rieman, M.F.J ., Redmiles, D.: Usability evaluation with the cognitive walkthrough. In: CHI '95 Proceedings, ACM (1995)Google Scholar

25.25.

APKM: Smart Campus Guidelines-Draft. APKM-Smart Campus Draft Version 123/ 05/2015Google Scholar 
Esaki, H.: Smart Campus Implementation Based on Internet-by-Design. Green University Tokyo Project. Internet Society (2015)Google Scholar

Azeta, A.A., Igbekele, E.O., Azeta, V.I.: Moving from Web-of-Things to Voice-ofIntelligent-Things in e-Campus. In: AFRICON, 2017 IEEE. IEEE (2017) Google Scholar

28.28 .

Nuance: http:// www.nuance.com, 2002, as of 15 March 2002

29.29.

SpeechWorks: http:// www.speechworks.com, 2002, as of 15 March 2002

TellMe: http:// www.tellme.com, 2001, as of 15 March 2002

Beck, J .E., J ia, P., Mostow, J .: Automatically assessing oral reading fluency in a computer tutor that listens. Technol. Instr. Cognit. Learn. 2, 61- 81 (2004)Google $\underline{\text { Scholar }}$

Rickel, J ., J ohnson, W.L.: Task-oriented collaboration with embodied agents in virtual worlds. In: Cassell, J ., Sullivan, J ., Prevost, S., Churchill, E. (eds.) Embodied Conversational Agents, pp. 95- 122. MIT Press, Cambridge (2000)Google Scholar

Iera, A., Morabito, G., Atzori, L. (eds.): The Internet of Things. Springer, Berlin (2010). ISBN: 978-1-4419-1673-0zbMATHGoogle Scholar

\section{Copyright information}

(C) Springer Nature Singapore Pte Ltd. 2020

- DOlhttps://doi.org/10.1007/978-981-32-9949-8_47

- Publisher NameSpringer, Singapore

- Print ISBN978-981-32-9948-1

- Online ISBN978-981-32-9949-8 
- eBook PackagesEngineeringEngineering (R0)

- Buy this book on publisher's site

- Reprints and Permissions

\section{Buying options}

Chapter

EUR 24.95

Price excludes VAT

- DOI: $10.1007 / 978-981-32-9949-8 \_47$

Springer Nature

(C) 2020 Springer Nature Switzerland AG. Part of Springer Nature.

Not logged in Not affiliated 165.73.192.253 